\title{
Mechanism of state regulation of competitiveness of tourist territory Krasnodar territory, Russian Federation
}

\author{
Elena Vorobey $^{1, *}$ and Tatyana Borisova ${ }^{2}$ \\ ${ }^{1}$ Sochi State University, Sovetskaya str., 26a, 354000, Sochi, Russia
}

\begin{abstract}
In modern conditions the necessity of active actions in eliminating of disproportions in national Russian Federation economy, solving difficult regional problems, creation of conditions for sustainable development for all territories is increasing. The article deals with the mechanisms of the state support of competitiveness of tourist territory Krasnodar region, Russian Federation and promising areas of it's improvement.
\end{abstract}

\section{Introduction}

State regulation of regional development through the economic mechanism is used at different levels of governing: federal, regional, interregional and local. The federal government should regulate the organization of production in extreme areas and developing areas. Then the federal government should pay attention to environmental and social program, the organization of interregional economic relations. Regional government focuses on the use of local resources, the optimization of business, environmental and social problems.

The regional specifics predetermine the using of a certain set of economic levers and incentives in each particular case. For successful implementation of economic reforms regional specifics should be taken into account during the implementation of the main directions of national policy.

\section{Materials and methods}

In the field of financial and fiscal policy it is necessary to increase the share of regional budgets in total budgetary resources. At the same time, it is necessary to ensure the functioning of the horizontal and vertical redistribution of income between regions throughout the territory of Russian Federation. Such a multi-channel system is necessary for independent, stable budget revenues and for financing programs under the jurisdiction of Federal government.

\footnotetext{
* Corresponding author: vorobei.sochi@yandex.ru
} 
At the same time, based on the level of economic and social development, unemployment, ecological situation in the regions, an individual regional approach is needed. Centralized resources (subventions) from the federal budget are to be allocated to the regions to solve problems which can not be solved by other sources of financing. For example: natural disasters and emergencies, critical social problems and etc. For financing regional programs government resources are needed. It is necessary to finance regions to achieve the best economic indicators.

The main purpose of regional social policy is to prevent acute social conflicts in the regions, to remove tensions in areas of increased social danger. Special attention should also be paid to the social development of the areas of residence of small nationalities of Russian Federation. The main source of financing regional social programs became the budgets of the republics, territories, regions and local budgets. In order to support lowincome groups of the population, the Republican federal and territorial funds for social support have already been formed. The main means of implementing social policy are:

- $\quad$ provision of budgetary and extra budgetary subsidies,

- increasing of salaries in budget sectors,

- $\quad$ establishing of the extra payments to pensions, benefits, etc.

In the conditions of reducing state centralized capital investments, the main emphasis should be placed on creating the conditions for attracting private funds and creating conditions for development of public-private partnership, to strengthen investment policy. It is necessary to stimulate projects that make it possible to rationalize the territorial structure of business to raise the level of regional economy and to solve the most important national economic problems.

\section{Results}

Socio-economic characteristics of the regions require not only the development of regionally differentiated measures of economic reforms, but also stipulate minimum requirements for the centralization of resources at the federal level and their interregional redistribution. It is one of the most important condition of stability, reliability of the socioeconomic and political systems of the Russian Federation. The need for state support for crisis regions, as well as for ensuring interregional communications, predetermines a large amount of centralized investments. Maintaining the standard of living of the population in all regions (even regardless of their economic situation) requires the accumulation and interregional redistribution of budgetary resources and activity from the region itself.

In the conditions of intensifying of economic reform, the formation of the labor market and the regulation of employment process are the most important problems.

State regulation of sustainable development of regional economy is carried out through various methods. The content of these methods depends on the production base of territorial entities, socio-economic relations, the specifics of the problems to be solved, etc. The planned and ongoing activities can be classified according to different craterous:

- administrative and economic;

- direct and indirect effects;

- the use in conditions of stationary development and during periods of crises;

- human resources;

- scientific and analytical support;

- etc.

In the system of territorial management, measures are taken to identify special features that have yet to be effectively managed. 


\section{Discussion}

The mail goal of developing competition in the regions of the Russian Federation is to identify the potential of economic development, including the scientific, technological and human potential. Besides that the developing of competition in the regions of the Russian Federation should provide the conditions for the development, support and protection of small and medium-sized businesses and the elimination of administrative barriers. The standard for the development of competition in the regions of the Russian Federation was developed as an action plan (so named "road map") "Development of competition and improvement of the antimonopoly policy" approved by the Government of the Russian Federation in 2012. The standard for the development of competition in the regions of the Russian Federation is approved by law of the Government of the Russian Federation of 05.09.2015. №1738.

The principles of the implementation of the standard are:

- customer orientation, the interest of the top manager of the region (governor),

- systematic approach - in the analysis of markets, transparency of actions and increasing consumer and producer satisfaction in socially important and priority markets of the Krasnodar Territory.

In the Krasnodar Territory a list of competitive markets is established. It consists of a list of priority markets and a list of socially important markets. The choice of each market from priority or socially significant markets is justified, and target indicators for such markets are established.

In our opinion, the implementation of the standard for the development of competition in the regions of Russian Federation will make it possible to bring business to a unified level of economic development, creating conditions for healthy competition between them.

Instability in the country and regions was stimulating the development of partial problems:

- budget and budget relations;

- crisis management;

- $\quad$ supply of foodstuffs and industrial goods\$

- etc.

This entailed new contradictions between the momentary orientation of managerial concepts and the corresponding decisions, the inertia of territorial socio-economic systems, the challenges of development in the medium and long term.

State regulation is ongoing, but methods, purposes and priorities should be historical for each region. There are some general directions of state regulation, which have been actively implemented recently:

1. A complex of legislative, executive and supervisory measures that are carried out by eligible institutions and public organizations in order to adapt social and economic structures and processes to the conditions created by market relations.

2. Revision, adjustment, addition of objective economic laws, regularities and tendencies. This is a normal reaction of the self-defense of the market relations from the deficiencies inherent in its mechanisms, which determines the need for appropriate regulatory actions.

3. State regulation with a certain level of economic development, concentration of production and capital, their spatial differentiation.

4. State regulation in the "narrow" (subsidies, financing, procurement, state orders, etc.) and "broad" means (creation of general economic and other prerequisites and conditions for the effective operation in the regions of market-based economic mechanisms, for choosing by economic and infrastructural institutions the best ways of their activities with an orientation towards national purposes and goals). 
5. Search for a compromise between numerous and diverse, sometimes multidirectional interests.

One of the most important issues of the implementation of regional policy at all levels are various tax and budgetary mechanisms. This mecanisms form the basis of budgetary federalism as a system of fiscal relations between government and management at various levels. The instruments of budgetary regulation can be divided into two main groups:

- $\quad$ normative methods (these are different types of transfers received by the budgets of territories from higher budgets);

- special budgetary regimes (a complex of fiscal measures aimed to create a favorable investment climate in depressed and industrial areas and attract private national and foreign capital).

Currently, in the Russian Federation budget sector, two options can be applied to strengthen the financial base of the regions. The first is the redistribution of the total budget in favor of regions. The second is the creation of a mechanism for the region's interest in earning its own funds. The second option is more perspective. It leads not only to the increase of financial resources of each territory, but also means an increase in the federal budget. The basis of the majority of regional fiscal systems is formed by regional budgets, regional taxes, fees, benefits, subsidies, subventions, regional financial and tax relations with the federal center and other levels. Such systems should have a targeted regional orientation, be accessible for execution, have reasonable principles for the formation and spending of funds, and also take into account regional and state interests.

The financial support of the regions is one of least formalized and most flexible direction of regional policy. The explicit and hidden interests of the state and regions become apparent here. The most visible become the subjectivism, the connection of political conjuncture and regional lobbying for decisions. The state shares with the regions using not only direct budget injections by federal-branch or federal-regional financial channels.

We must also bear in mind state decisions, establishing clear proportions of distribution of federal and other types of taxes, tariff and license benefits, of allocating funds for one-off acts of financial support for different regions, for the development and implementation of regional programs, etc. The implementation of budgetary and fiscal policy is one of the main mechanisms of modern Russian Federation regional policy. Budgetary and tax policy in Russian Federation takes a key position both in relations between the federal center, regions of the Russian Federation, and between the organs of state management of the Russian Federation, regional management and local self-government organs. Mainly, the local self-government relies on significant historical, cultural, economic, demographic peculiarities and traditions of a particular territory, which impose a certain imprint on the activities of local self-government organs. For Russian Federation, as a country of multinational and very territorially differentiated, this aspect of the functioning of local self-government organs is very important. It should be noted that municipal formations are not monolithic, but consist of various smaller units: cities, urban districts, village councils, etc. All small units may also have their own local government and their budgets, in connection with which local inter-budgetary relations within the municipal formations themselves can appear.

If the distribution of taxes between the federal budget and particular territories is specific, the distribution of income within the regions of the Russian Federation changes every year and depends entirely on the decision of the regional management.

Interregional differences in the level of budget revenues are characterized by such indicator as own per capita income. The higher the level of the gross regional product in the region, the industrial and agricultural production is, the lower is the unemployment, and accordingly, the income of the population raise, the greater becomes the tax base and more 
taxes are collected in the region. In addition, per capita income is influenced by natural and climatic conditions and the distance of the territory from the central regions. Influence is mediated: climate severity, long distances lead to the growth of prices, increased payments to the population, which is reflected in the revenue base. It is important to take into account that the differences between regions in terms of natural and climatic conditions, social characteristics determine the difference not only in budget revenues, but also in expenditures.

In the Krasnodar Territory, the level of per capita income is higher than the average region in Russian Federation. The income base of this region is largely determined by the level of socio-economic development, natural and climatic conditions. The last factor is of particular importance for the Krasnodar Territory. Favorable climatic conditions are one of the main factors determining a relatively low level of prices. The tax policy of the regional government is influenced by interregional differences in their own revenue base:

- the number and rates of regional and local taxes;

- the scope of the provided tax benefits;

- administration of taxes.

As known, the main purpose of the budgetary regional policy is to equalize the budget provision. The main source of providing funds to the regions from the federal budget is the Federal Fund for Financial Support of the Federation's Subjects (similar funds can exist at the regional levels to provide funds for the local budgets).

Along with the differences in the levels of budget provision between the regions of Russian Federation, it is very important to learn internal regional differences. In fact, there is a three-level budget system in the regions. The first level is regional budgets, the other two are local budgets, which are subdivided into local first-level budgets (districts and cities of regional subordination), and local second-level budgets (budgets of subordinate cities, village and rural budgets). There are no any interregional differences in the degree of decentralization.

The construction of interbudgetary relations is determined by the regional government, but all regions are united in one feature: local budgets (especially the second level) depend to a large extent on the enumerations from higher budgets. In order to equalize the budget security of municipalities in the regions (in addition to establishing differentiated standards for tax deductions), local budgets receive financial assistance from regional budgets. At the same time, two different approaches are used in the regions.

The first approach is granting (less often subventions), the volumes of which for individual municipal formations are, as a rule, the results of direct settlements and approvals between regional and local governments and established in the annually approved laws on regional budgets in absolute amounts. Such a mechanism is used in the Krasnodar Territory. Another approach is a form-based one - provision of financial assistance in the form of transfers from a special fund, created for these purposes.

The main share of the costs of the consolidated budgets of the regions is made up of socially-oriented expenditures; they make up 3/4 of all regional costs in Russian Federation as a whole. The share of local budgets in socially-oriented costs is much higher than in expenditures in general. This is understandable: industrial, agricultural policy is determined primarily by regional governors, while financing of social spending is expedient to carry out at the grassroots level.

Law-enforcement activities are financed mostly from regional budgets, and expenditures on housing and communal services are financed from local budgets. Such distribution of expenditure powers emphasizes the special importance of problems of budgetary security of municipal entities and objectivity of rendering them financial assistance from the regional budget.

The main document that determines the implementation of the budgetary policy of the 
Krasnodar Territory in relation to municipalities (local budgets) is the Law on the Budget of the Krasnodar Territory, which sets the normative of allocation of taxes to local budgets, the amount of financial assistance to local budgets (subventions). The feature of the Krasnodar Territory is the unity of the regional budget and local budgets. The Legislative Assembly of the Krasnodar Territory approved the regional budget for 2018 with the following characteristics:

1) the total amount of income in the amount of 212671070,8 thousand rubles;

2) the total amount of expenses in the amount of 212401462,2 thousand rubles;

3 ) the surplus of the regional budget in the amount of 269608,6 thousand rubles.

Also, the main characteristics of the regional budget of the Krasnodar Territory for 2019 and 2020 are:

1) the total amount of revenues for 2019 is 214344569,3 thousand rubles and for 2020 is 219872110,7 thousand rubles;

2) the total amount of expenses for 2019 is 214244569,3 thousand rubles, including conditionally approved expenses in the amount of 4997908,3 thousand rubles, and for 2020 is 219772110,7 thousand rubles, including conditionally approved expenses in the amount of 10364534,5 thousand rubles;

4) the surplus of the regional budget for 2019 is 100000,0 thousand rubles and for 2020 is 100000,0 thousand rubles [1].

Russian Federation is a country of large amount of resources and intellectual potential. At the moment, there is a sense of progress in trust in Russian Federation from investors. At the same time, Russian Federation's international image greatly influences the regions ability to attract foreign investment. In our country there are a certain number of prosperous regions where the risk of investors to lose their invested funds is minimized, and the resource potential is high. That is why the issue of assessing the investment attractiveness of the country as a whole, and of each region, is on the agenda. Effective investment policy is designed to create a favorable investment climate not only for the state, but also for private investors.

Without the investments it is impossible to raise the technical level of production and the competitiveness of domestic products in the internal and world markets. Naturally, the legislative and executive power should be engaged in investment policy not only at the federal, but also at the regional level. The responsibility of formation of a favorable investment climate in the territory lies on the regional government to attract private domestic and foreign investment.

In an increasing number of regions, local administrations are actively working to stimulate and support investment activities. Gradually formed a group of regions - leaders in the formation of investment culture and organization of the investment process. The increasing role of the regions in attracting investment is carried out in several directions. The main areas are:

1) development of regional investment legislation;

2) support for investments by local governments through the system of benefits;

3) formation of investment attractiveness of regions, their investment image, including catalogs of enterprises, catalogs of investment projects, etc.;

4) activities to attract foreign investment. The current political atmosphere on the world arena indicates a low attractiveness of Russia in general for foreign investors, but there are regions in which this attractiveness is comparable to that of Europe;

5) formation of investment infrastructure not only for production, financial, consulting, educational and technological entrepreneurship, but considering the future business and raising funds through franchising, crowd funding, vending, crowd sourcing, catering, car racing, coworking, etc.).

Today foreign investors can ignore the potentially favorable investment climate created 
in several regions of Russian Federation. Their activity does not correspond to a sufficiently strong local investment potential, nor to a relatively low risk. At the same time, investors lose not only their current benefits, but the prospects for tomorrow.

We would like to pay attention to the establishment in the modern regional practice of such a term as the "image of the region". The image of the region is a complex of certain features and characteristics that are associated emotionally and psychologically with a particular territory.

The formation of today's own image of each region and the strengthening of the moments of recognizability of the Russian territories are obvious. We hope that, in the long term, this helps to attract attention not only to Russian Federation as a whole, but to a particular region, will give an opportunity of efficient lobby of our interests among foreign investors, and for regions to improve the investment climate, to obtain additional resources for the development of the regional economy and to become a reserve of federal top managers. Moreover, the promoting of image of the regions is a promising way to overcome difficulties in shaping the image of Russian Federation as a whole.

The strategic target of the Krasnodar Territory development for the period until 2030 is the implementation of Russia's political, geostrategic and socioeconomic priorities in the south of the country and ensuring a radical improvement in the quality of life of population of the region on the basis of building the potential for advanced development [5].

The document that regulates the development of the Krasnodar Territory will be the strategy for the development of the region until 2030. This document is created to change the structure of budget spending, attract additional investment and ensure economic growth.

The strategy implementation period is 12 years. The year 2018 will be adaptive, but new regional programs will be worked out. While implementing the Development Strategy of the Krasnodar Territory until 2030, investments in the region will amount to 15 trillion rubles.

Within the framework of Strategy 2030, territorial zoning is carried out depending on the specialization of the districts, purposes and objectives of development. Seven economic zones of the Krasnodar Territory are identified. It is supposed to implement such flagship projects as South ExIm Hub, Cluster of Ecological Agro-Industrial Complex with Deep Intelligent Processing, Tourist-Recreational Cluster, Smart Industry Cluster, Cluster of Social and Creative Industries, Space without borders and Smart Kuban - leaders of the future (Smart Kuban). This projects are planned to implement with the help of a number of priority programs in each direction [2].

Proceeding from the main directions of the federal policy, the Strategy for the development of the industrial potential of the Krasnodar Territory, as well as the Strategy for the Development of Municipalities of the region, extending the tasks in the field of attracting investments and specifying the list of investment projects, were developed and approved.

\section{Conclusions}

The result of measures taken by the regional and local self-government is the increasing interest in the region as a promising region in Russian Federation. Annually, Krasnodar Territory is visited by numerous guests (16 million tourists in 2017), foreign delegations to strengthen partnerships and search for new areas of cooperation, attracting additional investment in the economy of the region (at the 2018 investment forum in Sochi, agreements were concluded on large-scale investments. For example, the amount of investments only in the health-resort and tourist complex of the region in the coming years will exceed 8,9 billion) [3]. 


\section{References}

1. URL: http://www.gks.ru (12.12.2017)

2. URL: kuban.rbc.ru (12.12.2017)

3. URL: https://min.kurortkuban.ru/ (12.12.2017)

4. E.K. Vorobey, Attractiveness of Sochi tourist destination through the prism of economic indicators of the development, Proc. of Int. Conf. Tourism in transition economies: issues and challenges for destination competitiveness (2015)

5. T. Borisova, E. Vorobey, Journal of Economy and entrepreneurship 11, 10-2 (2017) 